\title{
Evaluations of Human Rights Trials and Trust in Judicial Institutions: Evidence from Fujimori's Trial in Peru
}

\author{
Ezequiel Gonzalez Ocantos \\ University of Oxford
}

The International Journal of Human Rights (forthcoming)

\begin{abstract}
This paper investigates the mechanisms via which evaluations of human rights trials affect trust in judicial institutions. Courts in established democracies have been able to amass a "reservoir of goodwill" among the public, which insulates their prestige from the polarizing impact of controversial decisions. Since the judicialization of politics in young democracies is a recent phenomenon, judiciaries in these countries lack this reservoir. High profile judicial events such as human rights trials are therefore likely to affect their standing among the public. I argue that there are two mechanisms driving this relationship, which are activated at different times during the proceedings: citizens' views about the fairness of trial proceedings, and perceptions of defendant culpability. I test the hypotheses using surveys conducted during the course of Fujimori's trial. The results shed light on the relationship between transitional justice and the strengthening of the rule of law in post-authoritarian settings.
\end{abstract}

Key words: Transitional Justice; Public Opinion; Judicial Politics; Latin America; Fujimori 


\section{Introduction}

In recent years Latin America has experienced an explosion of trials against those responsible for perpetrating human rights violations during the dictatorships and armed conflicts of the 70s, 80s and 90s (Sikkink 2011; Collins 2010; González Ocantos 2012, 2014). ${ }^{1}$ Courts in countries like Argentina, Chile, and Peru have decisively put an end to the reigning impunity in the region, toppling down amnesty laws and presidential pardons, ignoring the exhaustion of statutory limitations, and sentencing former presidents, junta leaders and members of the military to years of imprisonment. Due to the attention elicited by these moments of high political drama, many Latin Americans have been systematically exposed to images and symbols of the judiciary at work, possibly affecting their opinions of courts in general (Smulovitz 1995). In this paper I investigate whether different aspects of citizens' evaluations of human rights trials (opinions about procedural fairness and defendant culpability) are correlated with trust in judicial institutions. I use surveys fielded at different points in time during the trial against

\footnotetext{
${ }^{1}$ I would like to thank Chad Kiewiet de Jonge and two anonymous reviewers for their excellent comments on earlier versions of the paper. All errors are my own. The fieldwork was conducted with the support of a Dissertation Year Fellowship granted by the Kellogg Institute of International Studies at the University of Notre Dame.
} 
Alberto Fujimori in Peru to study the mechanisms via which experiencing these events is associated with individual short-term attitudes toward the judiciary.

Scholars have extensively debated the pros and cons of holding human rights trials. ${ }^{2}$ Cross-national studies demonstrate, for example, that trials do not necessarily harm democracy or exacerbate political conflict (Sikkink and Walling 2007), and that they can even deter future human rights violations (Kim and Sikkink 2010). Analyzing the relationship between citizens’ perceptions of human rights trials and trust in judicial institutions is important in order to further evaluate the contribution of these trials to the consolidation of democracy. As Kim and Sikkink put it, human rights trials are "high-profile symbolic events that communicate and dramatize norms” (2010: 940). Apart from advancing victims' right to truth and justice, human rights trials are thought to strengthen the rule of law by sending a clear message that no one is above the law, that the costs of subverting the democratic order are high, and that in a democracy even those who perpetrated the most heinous crimes are guaranteed a fair day in court (Acuña and

2 This debate has focused mainly on the effect of trials on democratic consolidation. For arguments against trials, see Hintington (1991), Zalaquett (1992), and Snyder and Vinjamuri (2004). For arguments in favor of trials, see O’Donnell and Schmitter (1986), Méndez (1997), and Acuña and Smulovitz (1997). 
Smulovitz 1997; Teitel 2000). In other words, holding these trials is often seen as a way to strengthen the legitimacy of the legal system, and democratic rule more generally. In a democracy, enhancing the authoritativeness of law enforcement through perceptions of the resoluteness, fairness and impartiality of procedures is crucial in order insulate judicial legitimacy from citizens’ preferences vis-à-vis contingent case outcomes, and encourage voluntary compliance with unfavorable decisions (Tyler 1984, 2001; Rottman 2007). Empirically, if claims by the proponents of transitional justice are true, positive evaluations of how the trials are conducted should be associated with higher levels of individual trust in judicial institutions, at least in the short term.

Investigating this relationship is also relevant because it can shed light on whether these trials are related to broader processes of judicial empowerment. If positive opinions about how human rights trials are conducted are associated with higher levels of trust in the institution, trials may be capable of strengthening judges by cementing loyalties among certain constituencies. This support can give them extra leverage in their confrontations with other branches of government. In contexts of high institutional uncertainty, such as those characteristic of executive-judicial relations in Latin America (Pérez-Liñán and Castagnola 2009), it is important to understand the conditions under which courts are able to survive these fights. Recent work in comparative politics explores the relationship between courts and public opinion as an important dimension of judges' ability to 
become influential policy players (Vanberg 2001; Staton 2010; Helmke and Staton 2011). Courts' public legitimacy, the argument goes, can compensate for their lack of control over the purse and the sword (Caldeira 1986; Baum 2006).

The political drama and media attention that surrounds human rights trials increases the likelihood that they might affect individual attitudes towards courts. The legitimacy of courts in young democracies is highly susceptible to the impact of salient decisions or political events such as these trials, because as many have argued, the high profile participation of judges in political discussions is a relatively recent phenomenon in these regimes (e.g. Tate and Vallinder 1995; Hirschl 2008). Unlike their counterparts in developed countries, courts in young democracies are yet to amass a stable "reservoir of goodwill" among the public that insulates their prestige from political contingencies (Easton 1975; Gibson, Caldeira and Spence 2003; Gibson and Caldeira 2009). In addition to the factors usually associated with high levels of trust in judicial institutions in the developed world such as support for democracy or knowledge of courts (Caldeira 1986; Gibson, Caldeira and Baird 1998; Gibson and Caldeira 2009), it is therefore important to study how salient events associated with the performance of these judiciaries mold their legitimacy (Hoekstra 2000).

In this paper I specifically investigate if different aspects of citizens' evaluations of the Fujimori trial in Peru are significant individual-level 
determinants of trust in judicial institutions at different points in time during the course of the proceedings. The trial was a landmark in the recent wave of transitional justice in the region because it represented the first time that a former, democratically elected head of state was tried by courts in his own country for the perpetration of crimes against humanity (Burt 2009; Prusak 2010). It also represented a landmark in the history of Peruvian judicial politics. Before this trial, the Peruvian judiciary rarely played a prominent, active or autonomous role in political struggles. The literature characterizes courts before the 2000s as subservient and poorly trained (Hammergrem 1998; Dargent 2009; Pásara 2010). In particular, Fujimori's authoritarian shenanigans during the 1990s greatly affected judicial independence (Finkel 2008), so after the 2000 democratic transition some members of Peruvian high courts were at pains to bolster public trust in the institution. In this context, the trial was a turning point, throwing the judiciary into unchartered political territory, and represented both a challenge and an opportunity in the process of gaining power, prestige and influence. Like never before the judiciary found itself in the media spotlight, increasing the legitimacybuilding potential of the proceedings.

The argument I present uses insights from the literature on trust in courts and the legal system to suggest that there are two sets of attitudes related to perceptions of human rights trials that affect trust in judicial institutions: citizens’ views about the fairness of trial proceedings and perceptions of defendant 
culpability. However, each of these considerations matters differently at different points in time during the trial. At an earlier stage, perceptions of the extent to which due process is respected are what determines how exposure to the trial affects trust in the judiciary. As the trial progresses and a ruling for or against the defendant is imminent or has already been handed down, perceptions about procedural fairness become less important than beliefs about defendant culpability. As citizens consolidate outcome-related opinions against which they can evaluate judicial behavior, the relationship becomes politicized reducing the impact of process evaluations. To test the argument I use three surveys conducted by the Institute of Public Opinion of the Catholic University of Peru at different points in time during the trial (several weeks into the proceedings, weeks before the ruling, and a month after the ruling.)

The Fujimori trial is a particularly suitable case for evaluating these mechanisms linking perceptions of human rights trials and trust in judicial institutions. Since we know very little about the relationship under scrutiny, it makes sense to explore a case in which it is likely that citizens formed consequential opinions about a human rights trial, the actors involved, and the proceedings. If we do not find that opinions about the proceedings or defendant culpability affected individuals' views of the Peruvian judiciary, it will make little sense to further explore how human rights trials shape judicial legitimacy in other cases in which trials were present, but were less dramatized, mediatized, or 
politically salient. If by contrast we do find that positive evaluations of the trial are associated with more favorable attitudes towards courts, it will be plausible to suggest that given similar levels of public visibility and drama, evaluations of human rights trials have the potential of creating constituencies of support for the judiciary.

The paper proceeds as follows. First I review the literature on the sources of judicial legitimacy in the developed world. Second, I describe the significance of human rights trials as legitimacy-building events in developing democracies, and explain my hypotheses linking perceptions of human rights trials and trust in courts. Third, I present a brief history of the Peruvian judiciary and an overview of the Fujimori trial. Fourth, I describe the surveys used to test my hypotheses and the main variables included in the analysis. Fifth, I analyze the results of several ordered logistic regressions. Finally I discuss the implications of the findings and conclude.

\section{Trust in Judicial Institutions}

Scholars are becoming increasingly interested in the role of public opinion in transitional justice processes. For example, Gibson explores how the availability of different justice mechanisms affects attitudes towards amnesties in 
South Africa (Gibson 2002). In several studies, the ICTJ analyzed levels of support for transitional justice in conflict-ridden societies, and found that in the DRC, for example, few people want the judiciary to be in charge of the process (2004; 2008). In a more recent paper, Aguilar et al. (2011) find that younger, nonreligious, left-leaning respondents, and those whose families were victims of Franco’s dictatorship are more likely to support transitional justice in Spain. Finally, Nalepa (2010) rejects the view that lustration policies in Eastern Europe were guided by public opinion. This article contributes to this growing literature by asking a different kind of question. How do perceptions of human rights trials shape attitudes towards the judiciary? In order to answer this question it is important to first review what we know about the sources of trust in courts.

Studies of the United States’ Supreme Court point to several factors that shape public attitudes towards the institution. Gibson (2007) finds that support for the court is associated with holding democratic values. Mondak and Smithey (1997) suggest that democratic values are related to an enduring positive predisposition towards the court, which becomes the default judgment in the absence of circumstantial dips in overall levels of prestige. High esteem for judicial institutions is also related to individuals' knowledge of courts (Gibson and Caldeira 2009). Since courts become known to people as a consequence of decisions that concern them, a little known court is unlikely to elicit either positive or negative evaluations. In this sense, high levels of support likely result 
from judgments handed down over a long period of time satisfying nonoverlapping constituencies (Gibson, Caldeira and Baird 1998). In addition, actual policy outputs have been found to affect support for the court in the long term (Caldeira 1986). Gibson and Caldeira (1992), for example, indicate that after 1968, when Supreme Court jurisprudence became more conservative vis-à-vis civil rights era judgments, African Americans expressed lower levels of support for the institution.

One of the most influential arguments in the literature is the contention that overtime courts generate a "reservoir of goodwill" among the public. This reservoir decisively insulates judges against the negative impact of certain decisions on their overall levels of public legitimacy (Easton 1975; Gibson, Caldeira and Baird 1998; Gibson and Caldeira 2009). "Exposure to the legitimizing symbols that all courts so assiduously promulgate” (Gibson, Caldeira and Baird 1998:356), helps create a myth of legality and impartiality (Casey 1974; Scheb and Lyons 2000). Individuals resort to this heuristic when exposed to judicial decisions. This cognitive framework reinforces the idea that courts are different from other institutions, devoid of power politics or spurious deals, and helps cushion the impact of judges' policy choices or other politicizing aspects of the judicial process (i.e. controversial confirmation hearings) (Gibson, Caldeira and Spence 2003). 
"Positivity theory,” as the above argument is known, associates long-term exposure to judicial symbols, and knowledge of the judicial system, with support for courts and their decisions. Because long-term socialization is such an important aspect of the argument, an implication of the theory is that when courts are young they are more susceptible to the impact of specific decisions or events on their overall levels of support (Gibson, Caldeira and Baird 1998). The relationship between courts' increasing salience in a political system and their legitimacy is therefore likely mediated by short-term evaluations of performance. It could be argued that high profile events or decisions in the formative years of a court's "reservoir of goodwill” can have an important effect on how the institution is perceived. This assumption is central to positivity theory, since as Gibson and Caldeira (2009) argue, the positive heuristic is not a natural predisposition but a social construct. In other words, there is a time in the life of a court when what it does and what is says decisively shape public attitudes towards it. Almost all of what we know about the sources of trust in courts comes from studies of established democracies, so we know very little about how shocks occurring when courts are yet to amass a stable "reservoir of goodwill" (e.g. human rights trials) affect the prestige of judicial institutions in young democracies.

It is important to note that courts in third wave democracies susceptible to the impact of these publicity shocks are not always "young" in terms of age, in part because regime transitions were rarely accompanied by large-scale personnel 
changes inside the judiciary or the creation of new courts. Moreover, these episodes of high exposure often come several years after the onset of democratization processes. However, these are "young" courts in the sense that they have only recently started to actively participate in high-stakes policy debates, weighing in on subjects that were previously the exclusive domain of generals and politicians, and autonomously influencing the political process. In Latin America, for example, the strong political pressures and colonization strategies designed by democratic and non-democratic leaders throughout the $20^{\text {th }}$ century resulted in a tendency towards judicial restraint (Oyahnarte 1972; Magaloni 2003; Pereira 2005; Hilbink 2007). In addition, the hegemony of certain variants of legal positivism made it unthinkable for judges to challenge the substantive policy choices made by the elected branches (Lopez Medina 2004; Gonzalez Ocantos 2014). Consequently, the systematic exposure of courts to intense public scrutiny or newspaper headlines is a relatively new phenomenon (Staton 2010). It is in this sense that I argue that courts in these democracies are "young," that they are yet to secure a stable "reservoir of goodwill," and that their legitimacy in the eyes of the public is prone to be affected by high profile events such as human rights trials. 


\section{How Do Evaluations of Human Rights Trials Shape Trust in the Judiciary?}

Trials that involve high profile defendants such as former presidents, members of military juntas, or leaders of large insurgent groups tend to be moments of intense political drama, which shine a bright spotlight on courts, and stir strong passions for and against the proceedings, the parties involved, and the outcomes. For citizens usually inattentive to the activities of the judiciary, this spotlight can thus offer a dramatic introduction to the workings of a previously opaque judicial system. For example, according to Smulovitz, after the historic 1985 trial Argentines discovered the law: “an unexpected effect of the initial enthusiasm with the "abilities" of the judiciary and of its judges has been the judicialization of social and political conflicts” (1995:73; my translation). Members of the judiciary became media stars like never before, revealing the “potentially subversive and mobilizing character of legal rhetoric” (ibid: 88; my translation). In the case of Chile, Alexandra Huneeus's work suggests that judges see human rights trials as an unparalleled opportunity to alter public perceptions of the judicial system. She argues that judges strategically used the exposure afforded by Pinochet era cases to seek atonement, and clean the image of the institution, tainted by past collaboration with the military regime and passivity in the face of egregious violations of human rights (Huneeus 2010). 
This scholarship indicates that by exposing citizens in a consistent manner to concrete, visible examples of the judiciary at work, human rights trials represent moments when individuals can form fresh opinions about how judicial actors conduct their duties in these specific cases, opinions that can have an impact on their overall attitudes towards the judiciary. In what follows I argue that human rights trials affect trust in the judiciary via two mechanisms. The first mechanism involves beliefs about the fairness of the proceedings, whereas the second is related to perceptions of defendant culpability.

Following Tyler (2001, 2004), perceptions of procedural fairness refer to views about the extent to which authorities respect the rights of the parties involved in a legal dispute, and generally care about their well-being. In the context of human rights cases, these are beliefs relative the way judges handle pre-trial proceedings such as extradition battles and scheduling, how they treat the defendant and the witnesses during the trial, or how they condition the ability of defense lawyers to adequately do their job. I expect citizens who believe that the defendant was offered a fair day in court to express higher levels of trust in judicial institutions.

A skeptical eye may argue that this relationship is endogenous. However, following the political science literature on public opinion and courts, it makes sense to assume that the causal arrow points from concrete experiences with 
judicial rituals to more general or abstract assessments of institutional performance (Gibson and Caldeira 2009; Gibson, Caldeira and Baird 1998; Hoekstra 2000). The expectation is also consistent with a recurrent finding by criminologists, linking perceptions of procedural fairness with the legitimacy of authority figures and defendants' likelihood to cooperate with them (Brockner et al. 2001; Sunshine and Tyler 2003; Fagan and Tyler 2005). Studies of citizen interactions with lower courts in the United States, for example, indicate that these short-term perceptions are more consequential in determining trust in courts than more structural characteristics such as race (Tyler 2001; Rottman et al. 2003; Rottman 2005).

Interestingly, scholars have also shown that when procedures are regarded as fair, their positive effect on defendants' views of courts or the police remains in place even if the individual experiences an unfavorable outcome (Tyler 1984). In the specific context of this article, it is therefore theoretically possible for the general public to believe that the right to due process was respected during the trial, and hence have a more positive view of the judiciary, even if s/he politically supports the defendant, or believes the case should have never been brought to court. In sum, the first hypothesis reads as follows: 
H1: Individuals who believe that the defendant was guaranteed due process are more likely to show higher levels of trust in the judiciary than those who believe the defendant was not offered a fair trial.

Although in the criminology literature studies often show that the public "is more attentive to procedural than to outcome fairness" (Rottman 2007: 840), given the high political stakes involved in human rights trials, and their controversial and polarizing nature, it is indeed possible that citizens' views about defendant culpability also affect trust in judicial institutions before and after the outcome of the trial is known (see Sarat 1977). For example, if individuals believe the defendant is guilty, and the court rules in the same direction they could be more likely to express higher levels of trust in the judiciary, what Ford (2012) calls "confirmatory bias.” But despite their obvious focus on outcomes, beliefs about defendant culpability can also have an impact on trust in the judiciary before the ruling is handed down. First, individuals' experience with the trial simultaneously allows them to form expectations about how judges will rule, and shapes their views about whether or not the defendant should be sent to prison. By contrasting those predictions with their pre-existing or evolving outcome preferences, they have a basis for evaluating the trial and the judiciary. These beliefs and attitudes could be a function of their trust in the different witnesses, their own assessment of the evidence presented in court, or the commentary they read or hear in the press. Second, and more importantly, beliefs about the 
innocence of the defendant, likely influenced by political assessments of the service he or she paid to the nation in the fight against "terrorists" or the radical left, can lead individuals to disapprove of the entire affair, and of the judiciary for being part of it, even before a verdict is reached. By the same token, those who believe the defendant is guilty may show higher levels of trust in the judiciary before the end of trial as a result of their satisfaction with the fact that the possibility of justice is finally within reach or that the defendant was at least held accountable in a court of law. I therefore expect that, all else being equal, those who think the defendant is guilty are also more likely to have a positive evaluation of the judiciary before the ruling is handed down:

H2: Individuals who believe the defendant is guilty are more likely to show higher levels of trust in the judiciary before the verdict is reached, than those who believe the defendant is innocent.

H2a: If the defendant is found guilty, this relationship is likely to remain positive; if the defendant is acquitted, the relationship is likely to become negative

These seemingly contradictory expectations can be reconciled by conceiving of the trial as a process, in which perceptions of procedural fairness and defendant culpability shape trust in courts differently at different points in time. In this sense, I contend that at first, trust in the judiciary is primarily affected 
by evaluations of procedural fairness. From the perspective of citizens following the trial through the media, what stand out at this point in time are the rituals involved and the interactions between the different actors. This is the moment when citizens begin to know the judges, and those first impressions about their behavior have an impact on how they perceive the institution as a whole (Olson and Huth 1998). In other words, people's levels of trust in the judiciary are not yet tainted by actual outcomes, but shaped by perceptions of whether courts meet standards of impartiality. For the average citizen views about defendant culpability are not as strong or articulated in the absence of long-term exposure to witness testimony or press commentary on the subject. Consequently, these attitudes are not as decisive in shaping their trust in the judicial system.

As the trial progresses, the salience of questions related to whether or not the defendant is innocent increases. After a protracted period of exposure to judicial proceedings and images of the defendant in court, the average citizen now has more information about case-facts in order to consolidate opinions about defendant culpability. Moreover, this long-term exposure is likely to exacerbate the aforementioned feelings of satisfaction with the judiciary among those who consider the defendant guilty, and reinforce feelings of indignation among those who view him or her as innocent, and therefore repudiate the decision to hold a trial in the first place. In this sense, it is important to note that media images of human rights trials can be extremely polarizing (Laplante and Phenicie 2009). For 
example, coverage of the evidence presented by the parties can not only sharpen existing views about defendant culpability making this set of beliefs highly salient in general evaluations of judicial performance, but can also modify the attitudes of previously indifferent spectators. Moreover, the media attention afforded by oral proceedings is often used by defendants to justify their crimes as part of a mission to save the country from left wing "terrorists" or foreign influences, further encouraging citizens to take sides (Ibid.). In other words, as the verdict is imminent or has already been handed down, the relationship between perceptions of human rights trials and trust in the judiciary becomes politicized: whether or not judges respected due process is no longer relevant; what matters is agreement with the decision to subject to defendant to a trial, and ultimately, with the court's ruling (Ford 2012).

H3: At the beginning of the trial evaluations of procedural fairness are more important than perceptions of defendant culpability in shaping trust in the judiciary. The relative importance of procedural fairness declines as the verdict approaches or after it is handed down, and that of defendant culpability increases.

\section{The Fujimori Trial}

In May 1980 Peru celebrated its first democratic presidential elections after 12 years of military rule. On Election Day, in a small village in the province 
of Ayacucho, an armed organization known as the Shining Path made a violent entrance into the national political scene burning ballot boxes. That episode was the prelude of a bloody internal conflict in which the armed forces and the national police confronted the terror tactics of a ruthless Maoist group (Stern 1998). Over the next decade and a half, the violent military campaign against the Shining Path would leave an estimated toll of 69,280 deaths. Both the military and the insurgents perpetrated crimes such as forced disappearances, extrajudicial executions, torture, and sexual assaults.

The conflict spanned across three democratically elected administrations presided by Fernando Belaúnde (1980-1985), Alan García (1985-1990) and Alberto Fujimori (1990-2000). In 1992 Fujimori staged a self-coup, putting an end to a decade of uninterrupted democracy (Tanaka 2005, 2006). Fujimori’s strategy vis-à-vis the Shining Path was particularly ruthless (Burt 2007; Villarán 2007). His tight alliance with the armed forces and the intelligence services led to the creation of a clandestine paramilitary group known as Grupo Colina, responsible for two of the most emblematic massacres of the period, Barrios Altos in 1991 and La Cantuta in 1992 (APRODEH 2008). Moreover, in 1995 Congress passed amnesty laws in order to exonerate military and police officers from their responsibility in human rights violations perpetrated during the conflict. 
According to the Final Report of the Truth and Reconciliation Commission, during the armed conflict judges and prosecutors became "agents of violence.” In the 1980s they abdicated their prerogative to investigate the crimes perpetrated by both parties involved in the conflict, and in the 1990s they passively endorsed and applied draconian anti-terrorist legislation, which resulted in systematic abuses of state authority (De la Jara 2001). The Final Report describes how prosecutors delegated their investigative duties to the police, systematically failing to check those proceedings in order to guarantee respect for civil rights and due process, as well as satisfactory outcomes. Similarly, judges recurrently allowed military tribunals to usurp jurisdiction in cases of state repression (Comisión de la Verdad y Reconciliación 2003).

The judiciary’s inability to perform its constitutional duties during that period can be attributed to three factors. First, the judiciary lacked adequate material resources. During the course of the 1980s and 1990s the judicial branch was never assigned more than 1.5\% of the states’ total expenditures (Comisión de la Verdad y Reconciliación 2003). This obviously had an impact on its capacity to conduct investigations that required among other things, expensive forensic tests and translators for the non-Spanish speaking witnesses. Second, judges did not have the necessary technical capabilities to adequately conduct their duties. The consensus in the literature and among practitioners interviewed during fieldwork in Lima and Ayacucho in 2010 is that Peruvian judicial actors suffered from 
enormous deficits (González Ocantos 2012). In the words of Peru’s most prestigious legal sociologist, "doctrinal training has separated [...] the law from its social consequences [...] The inoculation of a professional ideology within universities weakens the student's critical spirit [...] We have concrete evidence about the prevalent presence of mediocre professionals in the judiciary, with an inadequate or barely acceptable technical expertise” (Pásara 2010: 133-135). In this sense, until the 2000s Peruvian judicial actors ignored their duty to enforce checks and balances due to their lack of adequate training in "constitutional law and the lack of awareness of international human rights instruments” (Comisión de la Verdad y Reconciliación 2003, Vol. 3, Chapter 2, 255). Judges limited themselves to a "strict and mechanic enforcement of norms, without considering principles, values and fundamental rights” (ibid: 256). The influence of positivism and formalism led them to operate with a restricted interpretation of the reach of their formal prerogatives. For example, although the Peruvian Constitution grants judges the power of judicial review, ${ }^{3}$ it was rarely used. ${ }^{4}$ Finally, in the 1990 s Fujimori's authoritarian regime managed to colonize the judiciary with friendly

\footnotetext{
${ }^{3}$ Article 234 of the 1979 Constitution, and article 138 of the 1993 Constitution.

${ }^{4}$ Interview, Circuit Court Judge, March 26th 2010. This judge, who in the 1990s declared Fujimori's amnesty laws unconstitutional, recalled that in those days what she did was literally unprecedented.
} 
judges. To this end, numerous judges and prosecutors were sacked. When it fired a judge, the regime usually chose not to replace him or her with a permanent appointee. The national bench was thus populated with untenured judges in a deliberate attempt to obliterate judicial independence. Provisional judges and prosecutors feared losing their jobs if they contradicted the regime's wishes (Finkel 2008).

After a series of corruption scandals, Fujimori resigned and fled to Japan (Tanaka 2005). These surprising events were the starting point of a democratic transition, and created the momentum to alter this record of impunity by launching serious judicial investigations into the crimes perpetrated during the armed conflict (Burt 2009; González Ocantos 2012). With regards to Fujimori, after he was finally extradited in 2007 the Peruvian Supreme Court decided he would face three trials, the first of which concerned the serious human rights violations that took place during his presidency (Human Rights Watch 2009). The trial culminated with a historic ruling handed down in April 2009 in which he was sentenced to 25 years in prison for the crimes of aggravated homicide, assault and kidnapping. ${ }^{5}$ The Supreme Court judges in charge of the case argued that the status of Fujimori as a former head of state justified the maximum punishment

${ }^{5}$ Suprema Corte de Justicia de la Nación (Peru), Exp. $N^{o} 10-2001 /$ Acumulado $N^{o}$ 45-2003-A.V, ruling of April $7^{\text {th }} 2009$. 
allowed by Peruvian Law. Moreover, they concluded that under international law, the crimes in question constituted crimes against humanity. The trial received international acclaim for its fairness and impartiality. ${ }^{6}$

According to Prusak given "the high profile and politically sensitive nature of the trial, the Peruvian justices were hyper-vigilant in ensuring that the defendant was afforded all due process and procedural protections necessary to make the trial fair and legitimate” (2010: 889). For example, after the defense attorneys argued that Fujimori had serious health problems, the judges decided to shorten the daily hearings. The judges also made sure that the trial was broadcast live to the Peruvian public. To this end, they authorized a myriad of domestic and international observers to attend the trial. As one of the three judges told me in an interview, they were aware that the trial would be an unparalleled opportunity to introduce the judiciary to the Peruvian public:

For us it was an opportunity to show what a trial looks like. The support of the media was important in order to broadcast the trial to the whole country. It was a pedagogical opportunity. The trial was like a civics class taught on a massive scale. $^{7}$

In addition to the media exposure afforded by the trial, there are other reasons why it represented an unprecedented opportunity to shape public attitudes

${ }^{6}$ See Amnesty International (2009) and Human Rights Watch (2009).

${ }^{7}$ Interview, Peruvian Supreme Court Judge, Lima, May 28th 2010 
towards the judiciary. First, as the above quote suggests Peruvians were not used to paying attention to judicial politics, in part because the judiciary was perceived as epiphenomenal. The sheer subject matter of the Fujimori trial altered this pattern, drawing attention to a concrete display of judicial rituals. For example, in a survey conducted in January 2009, individuals were asked whether they “approved or disapproved of the performance in the trial of César San Martín”, the judge presiding over the hearings. He received a $37 \%$ job approval, and shockingly, only 34\% offered no answer, suggesting that the vast majority of the population could identify a Supreme Court judge by name. ${ }^{8}$

Second, the Fujimori affair came at a time when it was no longer a foregone conclusion that judges would be faithful servants of the powerful, blatantly biased or incompetent. For example, the percentage of untenured judges went down systematically since 2000, restoring some of the basic and formal safeguards of judicial independence (Justicia Viva 2006). In addition, following one of the recommendations of the Truth and Reconciliation Commission a special system within the judiciary was created to investigate the crimes perpetrated by both the Shining Path and state agents during the armed conflict. This facilitated the building of technical capacities among the relevant judges and prosecutors, including training in specialized investigative techniques for forced

\footnotetext{
${ }^{8}$ Survey details on file with the author.
} 
disappearances and other forms of macro-criminality, and the domestic use of international human rights law (González Ocantos 2012). By the time the Fujimori trial started in late 2007, early 2008, these courts had already convicted the leadership of the Shining Path and several military officers, showing signs of impartiality, effectiveness, competence, and courage.

These broader changes in the profile of the Peruvian judiciary are important in order to understand the context in which Peruvians initially processed the information about the proceedings against Fujimori in 2007-2008. When considering these contextual factors, the claim that at the start of the process the relationship between public evaluations of the trial and attitudes towards the judiciary was dominated by views about procedural fairness becomes more plausible. The judiciary had shown signs of change, so it made sense for individuals to assess whether in this particular case it behaved impartially. It was no longer a given that courts would be partial and subject to political manipulations. However, as the trial moved forward, additional factors came into play. In particular, the accumulation of media coverage polarized the public around questions related to state behavior during the armed conflict, politicizing the relationship between perceptions of the trial and trust in the judiciary. As a result, views about procedural fairness became less salient than views about defendant culpability. The next section introduces the data used to test these claims. 


\section{Data and Methods}

In order to study public perceptions of the Fujimori trial and their impact on trust in the judiciary, I use three surveys conducted by the Public Opinion Institute at the Catholic University of Peru. The Institute designed and fielded the surveys in October 2007, March 2009 and May 2009. All three were conducted in Lima's metropolitan area, which concentrates nearly a third of the country's population. Although the surveys are not nationally representative, they are representative of the portion of the population most highly exposed to the media, and hence to news about the Fujimori trial. ${ }^{9}$ This data makes it possible to gauge public attitudes at three critical moments during the saga: at the on-set of the proceedings, when the public had already witnessed how courts handled the extradition process and how they treated the defendant in preparation for the trial (October 2007); one month before the ruling was handed down, when the public had already experienced months of trial proceedings and the ruling was imminent

${ }^{9}$ The three surveys used multistage random sampling. The sample was stratified by city area; within each stratum the firm randomly selected a sample of blocks, and within each block a random sample of houses; finally, to select respondents within each household, the firm used age and gender quotas. The October 2007 survey had 419 respondents, whereas the March and May 2009 surveys had 476 and 470 respondents respectively. 
(March 2009); and one month after the ruling was handed down (May 2009). Although panel data would be ideal to test my argument, this design is promising because it allows me to explore the individual level determinants of trust in the judiciary, and whether the relevant determinants change in a short period of time.

To measure trust in the judiciary, all three surveys asked: "In general, do you have a lot, some, a little, or no confidence in the judiciary?” The scale was inverted so that 0 represents no confidence and 3 a lot of confidence in the judiciary. Figure 1 shows the distribution of responses. Although during this period Peruvians were generally distrustful of the judiciary, the mean level of trust increased from 0.66 in October 2007 to 0.9 in May 2009, a month after the Supreme Court found Fujimori guilty. The three average levels of trust in the judiciary are statistically different from each other $(\mathrm{p}<0.1)$, but the data points are not enough to make claims about the effect of the trial on judicial legitimacy in Peru overtime. These figures are consistent with other measures of trust in the Peruvian judiciary. For example, the surveys conducted between 2006 and 2012 by the Latin American Public Opinion Project asked Peruvians "To what extent do you trust the judiciary?” LAPOP uses a 7-point response scale where 1 is none 
and 7 is a lot. The average level of trust went up from 3 in 2006 and 3.04 in 2008, to 3.25 in 2010 and 3.36 in $2012 .{ }^{10}$

Figure 1. Trust in the Judiciary

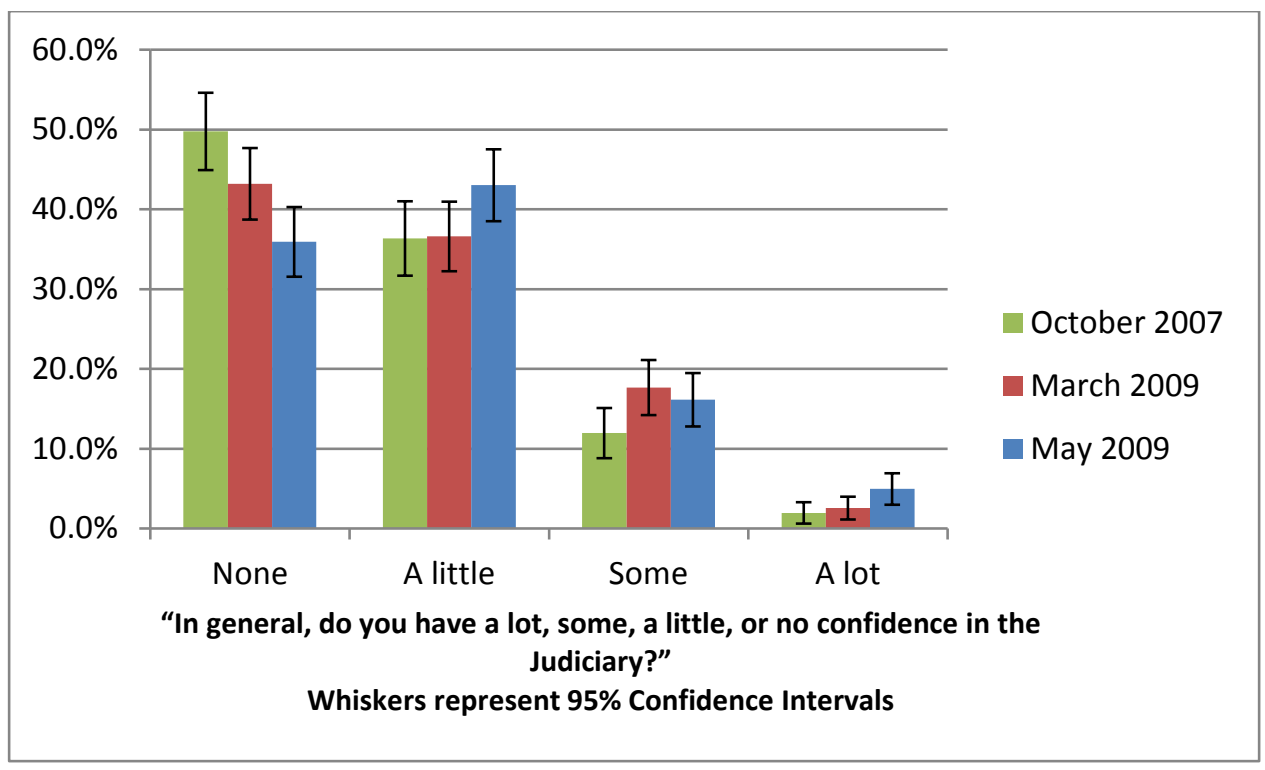

The available measures of the main independent variables, respondents' beliefs about procedural fairness and perceptions of defendant culpability, vary slightly across the three surveys. ${ }^{11}$ The October 2007 survey asked two questions. First, “According to what you know or have heard about the charges against Alberto Fujimori, would you say he is guilty or innocent of the human rights violations that he is accused of?" The answer options were "he is innocent"

10 See LAPOP's online data analysis system: http://lapop.ccp.ucr.ac.cr/cgibin/LapopDummiesFile.pl

11 This is a result of survey design, over which I had no control. 
(recoded as 0) and "he is guilty" (recoded as 1). Following this question, respondents were asked: “And, do you think that Alberto Fujimori will have a just and impartial trial in the judiciary?” The answer options were “No” (recoded as 0) and "Yes" (recoded as 1).

The March and May 2009 surveys had the same question format to gauge attitudes towards defendant culpability, but a different one to explore beliefs about procedural fairness. In March the question read as follows: "With regards to the trial that Alberto Fujimori has been facing for human rights violations (case Barrios Altos, La Cantuta and Sótanos del SIN), to what extent do you agree with the following statement? 'Alberto Fujimori's right to a good defense has been respected.’ Strongly Agree, Agree, Disagree, Strongly Disagree.” The 4-point scale was recoded so that 0 means "Strongly Disagree” and 3 "Strongly Agree." In May the question read as follows: "With regards to the trial that Alberto Fujimori faced for human rights violations (case Barrios Altos, La Cantuta and Sótanos del SIN), to what extent do you agree with the following statement? 'Alberto Fujimori's right to a good defense was guaranteed.'” The 2-point scale was recoded so that 0 means "Disagree” and 1 "Agree.”

Figures 2 and 3 summarize respondents' attitudes towards the fairness of the trial and defendant culpability. In the three surveys a majority of respondents thought that Fujimori was guilty, although as the trial progressed the number 
decreased. The differences in means are all statistically significant $(\mathrm{p}<0.05)$, with the exception of that between March 2009 and May 2009. During the period under study a solid majority believed in the fairness of the proceedings, and the number of people in this group increased overtime. The differences in means across surveys are also statistically significant $(\mathrm{p}<0.000)$. It is important to note that like with trends in the dependent variable, the data points are too few to be able to say anything conclusive about temporal changes in this set of attitudes.

Figure 2. Perceptions of Defendant Culpability (\% who believe the defendant was guilty)

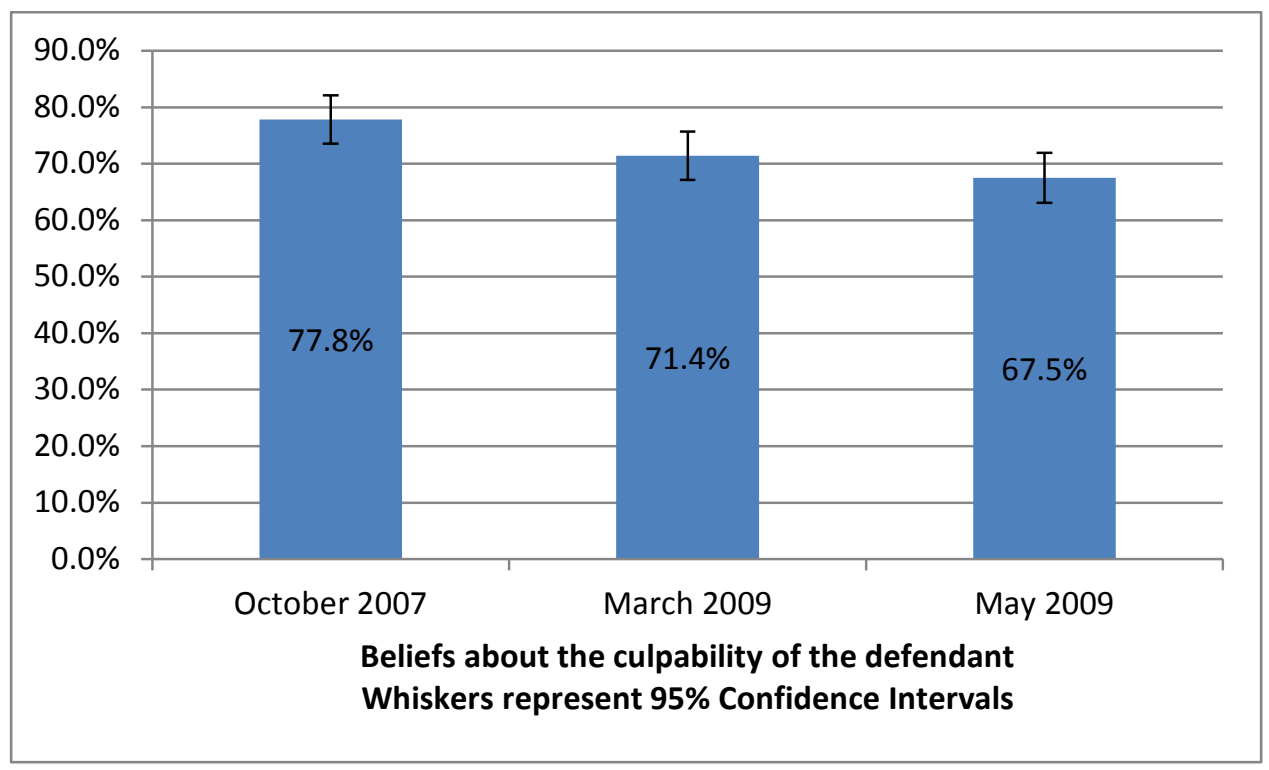


Figure 3. Beliefs About the Fairness of the Trial (\% who believe the trial was fair)

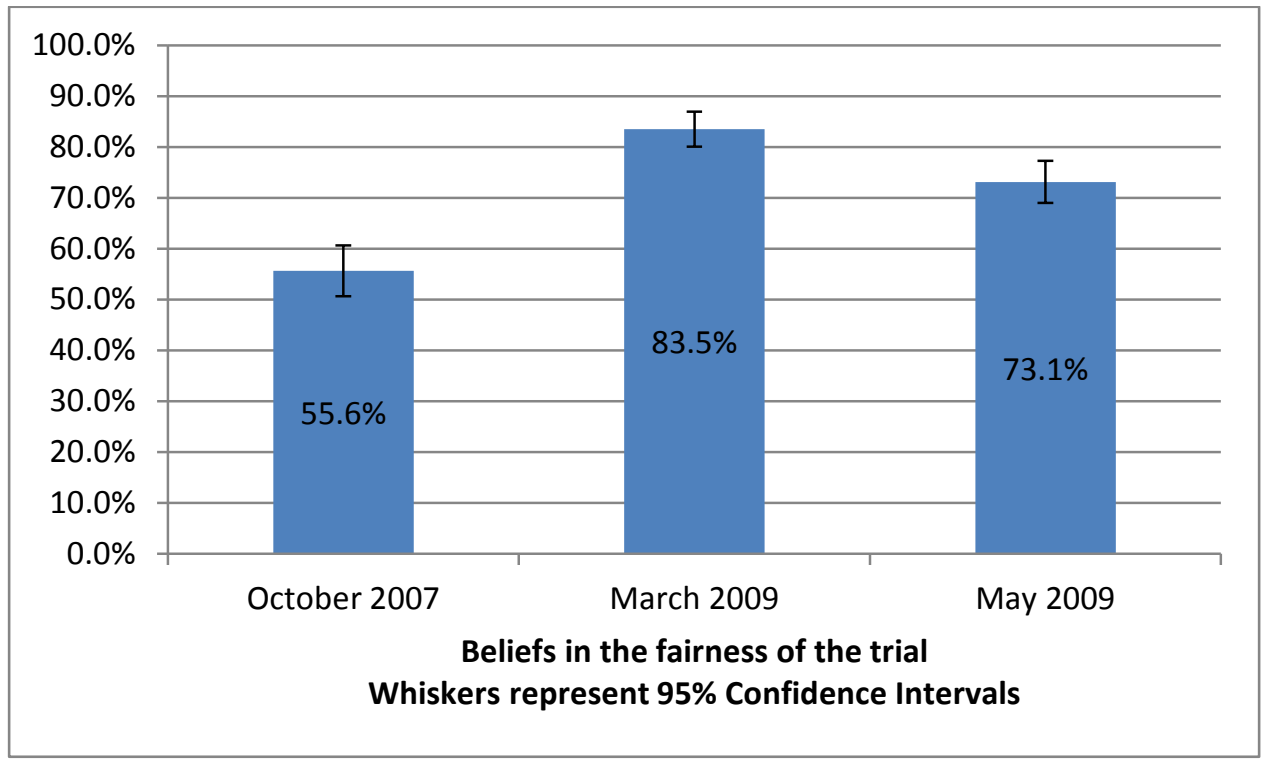

Note: For ease of presentation, the March 2009 data was collapsed into two categories: "Strongly Disagree/Disagree” and "Agree/Strongly Agree”

The analysis also includes a number of control variables. According to the literature on courts and public opinion in the developed world, satisfaction with democracy is a good predictor of trust in the judiciary (e.g. Mondak and Smithey 1997; Gibson 2007). To measure satisfaction with democracy the surveys asked: "In general, how satisfied are you with the working of democracy in Peru? Very Satisfied, Satisfied, Dissatisfied, and Very Dissatisfied." The variable was recoded so that lower values indicate less satisfaction with democracy.

At the time of the trial, Fujimori's daughter Keiko was a high profile and popular politician. As a result of Fujimori's indictment and the ruling against him, 
it is conceivable that support for Keiko could be associated with lower levels of trust in the judiciary. To explore this relationship I used the following question included in the survey: "In general, would you say you approve or disapprove of Keiko Fujimori’s job?” “Disapprove” was recoded as 0 and “Approve” was recoded as 1 .

I also included a variable that measures trust in the armed forces. On the one hand, because of Fujimori's tight alliance with the military, and because of the military's involvement in large-scale human rights abuses during the armed conflict, support for the armed forces could hurt trust in the judiciary. On the other hand, questions about levels of trust in different institutions tend to measure a latent general level of trust in the political system (e.g. Listhaug 1984; Lipset and Schneider 1987; Norris 1999; Cook and Gronke 2005; Ron and Crow forthcoming). If this is true, then support for the armed forces should be positively related to trust in the judiciary. To measure this independent variable I used the following question: "In general, do you have a lot, some, a little, or no confidence in the Armed Forces?” The 4-point response scale was recoded so that lower values reflect lower levels of trust.

In the Peruvian case the overwhelming majority of the victims during the armed conflict were indigenous or of indigenous descent. Aguilar et al. (2011) suggest that ethnicity and religiosity are associated with support for transitional 
justice due to the simple fact that state repression tends to affect "religious and/or ethnic groups unevenly” (1402). In the case of the present analysis, the link between ethnicity and the dependent variable (trust in the judiciary) is not as clear. On the one hand, the passivity of the judiciary during the conflict could lead these respondents to have lower than average levels of trust in the judiciary. On the other, due to the grievances that they suffered during the 1980s and especially during the 1990s, seeing Fujimori on trial could have led to higher levels of trust in the judiciary. To measure this variable I use a dummy in which 1 represents those respondents’ who consider themselves Quechua or Aymara.

The age of the respondent is also a relevant control. Given the record of the Peruvian judiciary it is possible that young people are in general more trusting of the institution than older people. The opinions of younger generations could be affected by the aforementioned post-transition changes, whereas those of older generations could be decisively molded by the memory of judicial ineffectiveness during the conflict.

Scholars have found a relationship between ideology and transitional justice. For example, in Spain right leaning respondents are less supportive of trials against members of Franco’s regime (Aguilar et al. 2011). With regards to the relationship between ideology and trust in the Peruvian judiciary, I expect that given the rightist orientation of Fujimori’s regime, right-leaning respondents are 
less likely to trust the judiciary. After all this is the institution that put the leader of one of Peru's right wing movements in jail. As a proxy of the respondent's ideology I included a question about economic policy preferences: "With which of these statements do you agree the most? 'Promoting the private market economy is the only way for Peru to develop' or 'Promoting a greater participation of the state in the economy is the only way for Peru to develop."’ Holding more statist, leftist views was coded as 0 and holding more pro-market, rightist views was coded as $1 .{ }^{12}$

Since the dependent variable is an ordinal variable, the analysis in the following section is based on a series of ordered logistic regression models. I first treat the surveys separately, and then pool the three waves in order to explore the moderating impact of time on the effect of the key independent variables.

\section{Results}

Table 1 shows the results of three different ordered logistic regressions, corresponding to each survey.

${ }^{12}$ In addition to the aforementioned controls, and following the literature on public opinion and trust in the judiciary, all models include demographic controls such as gender, socio-economic status and education (e.g. Gibson and Caldeira 2009; Hoekstra 2000). 
Table 1. Predicting Trust in the Judiciary I

\begin{tabular}{|c|c|c|c|c|c|c|}
\hline $\begin{array}{l}\text { Independent } \\
\text { Variables }\end{array}$ & \multicolumn{2}{|c|}{$\begin{array}{c}\text { Model 1: } \\
\text { October 2007 }\end{array}$} & \multicolumn{2}{|c|}{$\begin{array}{c}\text { Model 2: } \\
\text { March } 2009\end{array}$} & \multicolumn{2}{|c|}{$\begin{array}{l}\text { Model 3: } \\
\text { May } 2009\end{array}$} \\
\hline & Coefficient & S.E. & Coefficient & S.E. & Coefficient & S.E. \\
\hline $\begin{array}{l}\text { Procedural } \\
\text { Fairness }\end{array}$ & $0.76 * *$ & 0.25 & -0.22 & 0.21 & 0.07 & 0.25 \\
\hline $\begin{array}{l}\text { Defendant } \\
\text { Culpability }\end{array}$ & -0.08 & 0.36 & $0.48 * *$ & 0.24 & $0.56^{* *}$ & 0.25 \\
\hline $\begin{array}{l}\text { Satisfaction } \\
\text { with } \\
\text { Democracy }\end{array}$ & 0.28 & 0.20 & $0.50 * *$ & 0.18 & $0.80 * * *$ & 0.18 \\
\hline $\begin{array}{l}\text { Support for } \\
\text { Keiko } \\
\text { Fujimori }\end{array}$ & 0.34 & 0.32 & -0.32 & 0.23 & 0.06 & 0.24 \\
\hline $\begin{array}{l}\text { Trust in the } \\
\text { Armed } \\
\text { Forces }\end{array}$ & $0.44 * * *$ & 0.13 & $0.65 * * *$ & 0.14 & $0.39 * *$ & 0.13 \\
\hline Ideology & -0.04 & 0.25 & 0.14 & 0.22 & -0.11 & 0.22 \\
\hline Gender & 0.29 & 0.25 & 0.29 & 0.22 & -0.05 & 0.22 \\
\hline Age & $-0.02 *$ & 0.01 & $-0.02 * *$ & 0.01 & 0.00 & 0.01 \\
\hline $\begin{array}{l}\text { Socio- } \\
\text { Economic } \\
\text { Status } \\
\end{array}$ & -0.22 & 0.22 & -0.22 & 0.14 & 0.00 & 0.14 \\
\hline Education & -0.08 & 0.09 & 0.03 & 0.07 & -0.09 & 0.07 \\
\hline Indigenous & -0.28 & 0.28 & 0.18 & 0.23 & -0.07 & 0.24 \\
\hline Cut 1 & 0.17 & 1.35 & 0.04 & 1.22 & 0.76 & 1.14 \\
\hline Cut 2 & 2.10 & 1.37 & 1.89 & 1.21 & 2.74 & 1.16 \\
\hline Cut 3 & 4.40 & 1.43 & 4.42 & 1.17 & 4.52 & 1.20 \\
\hline $\mathrm{N}$ & 267 & & 345 & & 339 & \\
\hline
\end{tabular}

Note: ${ }^{*} \mathrm{p} \leq 0.1 ; * * \mathrm{p} \leq 0.05 ; * * * \mathrm{p} \leq 0.01$ Coefficients are from ordered logistic regressions.

The main independent variables in the models, "Procedural Fairness" and

“Defendant Culpability,” behave in the way I hypothesized. During the first 
period under study (Model 1), beliefs about procedural fairness are what shape trust in the judiciary, not perceptions of defendant culpability. After experiencing the extradition battle and other pre-trial judicial proceedings, respondents who came to the conclusion that the Supreme Court would conduct a fair trial were more likely to trust the judiciary, than those who thought it would not be impartial. Directly observing concrete judicial rituals and thinking highly of them boosted positive attitudes towards the institution as a whole. As I explained above, at this stage individuals were yet to form articulated opinions about defendant culpability, decreasing the saliency of those opinions when asked to evaluate the judiciary. As a result, the focus was on procedural issues, not outcomes or outcome predictions. Figure 4 plots the predicted probabilities of expressing "no trust" and "a lot of trust" in the judiciary, depending on whether individuals thought courts would respect due process. The whiskers represent 95\% confidence intervals. Believing in the fairness of the proceedings reduces the probability of not trusting the judiciary at all by 17 percentage points, whereas holding those same beliefs increases the probability of trusting the judiciary a lot by almost 10 percentage points. 
Figure 4: Beliefs in the Fairness of the Trial and Trust in the Judiciary (October 2007)

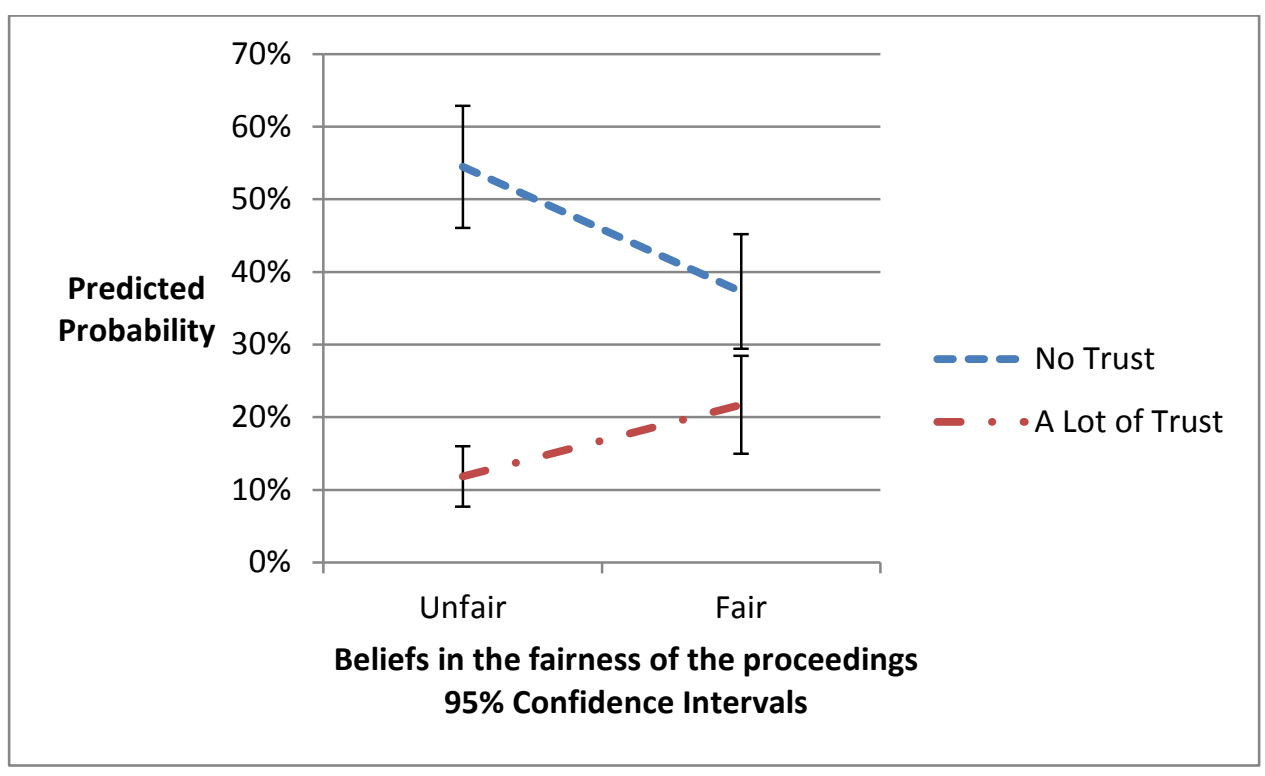

As the trial progressed, the story about the relationship between evaluations of human rights trials and trust in the judiciary changed. In the second and third models "Procedural Fairness" is no longer significant. Instead, perceptions of defendant culpability are what shape attitudes towards the judiciary. Thinking that Fujimori was guilty increases the probability of holding more positive views about courts in general. My argument indicates that after a protracted trial, when the ruling is imminent, citizens have more information to base their evaluation of the judiciary on their opinions about whether or not the defendant is guilty. Moreover, exposure to the trial reinforces feelings of satisfaction or indignation with the judiciary for its participation in the 
judicialization process, increasing the saliency of these attitudes when asked to evaluate the institution. If those opinions are later confirmed by a ruling, then they are also likely to support the judiciary. ${ }^{13}$

In order to show how attitudes toward the judiciary eventually became politicized, Figures 5 and 6 plot the predicted probabilities of not trusting the judiciary and trusting it a lot, depending on whether respondents believed the defendant was innocent or guilty. For example, one month before the ruling, in March 2009, believing that Fujimori was guilty reduced the probability of not trusting the judiciary at all by almost 13 percentage points; in May 2009 the impact was of 12 percentage points. By contrast, holding those same beliefs

13 It is worth noting that my argument is about the changing importance of different aspects of citizens' attitudes towards the trial in the cognitive process through which they form attitudes towards the judiciary. Whether or not the number of respondents who believe the defendant is guilty varies over time, as it is the case here, is orthogonal to the theory. We can still observe a positive and significant relationship in the later stages even if very few people ended up believing that Fujimori was guilty. Changes overtime do suggest, however, that people update their views during the course of the trial as they have more information about the defendant. 
increased the probability of trusting the judiciary a lot by 8 percentage points in March, and 9 in May. ${ }^{14}$

${ }^{14}$ The differences between Model 1 and Models 2 and 3 could be a function of the inconsistent operationalization of beliefs about procedural fairness in the second and third waves. In order to address this concern I ran two models using a different question to measure beliefs in procedural fairness. In the March survey the question read as follows: "With regards to the trial that Alberto Fujimori has been facing for human rights violations (case Barrios Altos, La Cantuta and Sótanos del SIN), to what extent do you agree with the following statement? 'The judges were impartial.' Strongly Agree, Agree, Disagree, Strongly Disagree.” In May the question read as follows: "With regards to the trial that Alberto Fujimori faced for human rights violations (case Barrios Altos, La Cantuta and Sótanos del SIN), to what extent do you agree with the following statement? 'The judges were impartial." These questions use the word "impartial," so they are closer to the October 2007 operationalization. The results are robust to this alternative operationalization. Additionally, I ran models using an index of procedural fairness that combines both measures. The results also remain the same. 
Figure 5: Beliefs in the Culpability of the Defendant and Trust in the Judiciary (March 2009)

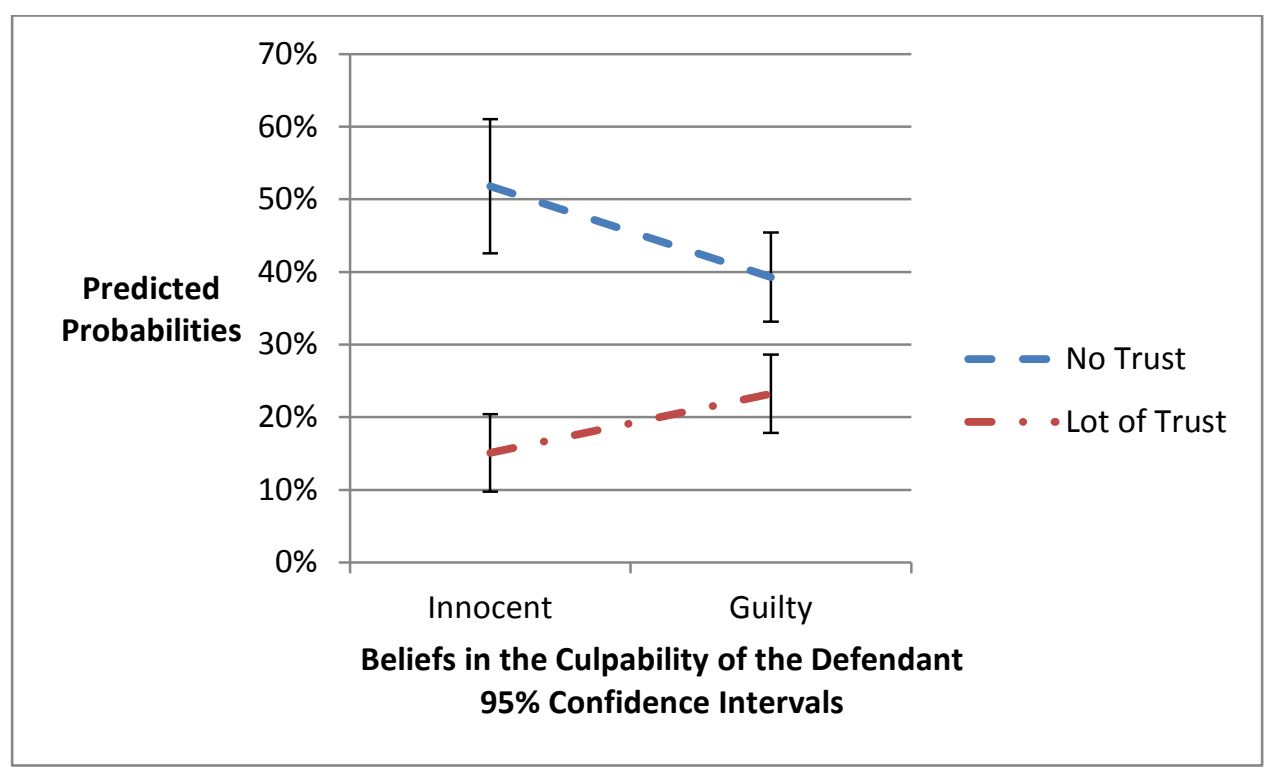


Figure 6: Beliefs in the Culpability of the Defendant and Trust in the Judiciary (May 2009)

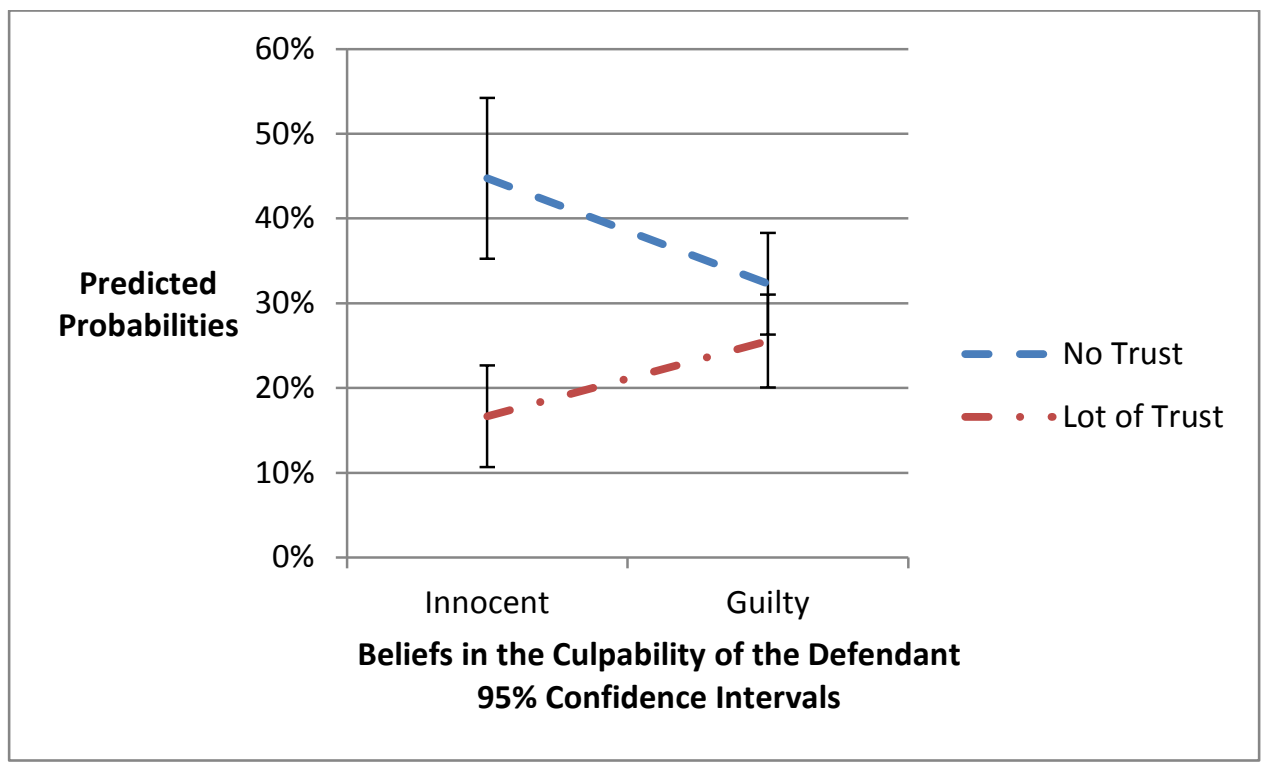

Other results worth noting include the coefficients for "Trust in the Armed Forces," which is the only one that remains significant across the three models. Higher levels of trust in the military increase the likelihood that individuals will be more trusting of the judiciary. This is consistent with the literature on political system support and institutional trust, which sees trust in different parts of the political system as highly interdependent. (e.g. Lipset and Schneider 1987; Norris 1999; Cook and Gronke 2005). The regression coefficients therefore question the alternative hypothesis, which argues that the military's involvement in human rights abuses and the multiple charges that some officers faced in Peruvian courts at the time, should lead to a negative relationship between the variables. With 
regards to "Satisfaction with Democracy," in all three models the coefficient is positive, although it is only significant in the March and May 2009 regressions. This is not surprising since one of the most consistent findings in the literature on public opinion and judicial legitimacy is that higher levels of satisfaction with democracy are associated with higher levels of trust in judicial institutions (Mondak and Smithey 1997; Gibson 2007; Gibson and Caldeira 2009). Finally, as hypothesized, older people tend to trust the judiciary less, although the coefficient is only significant in the first two models. This result is consistent with the idea that recent transformations in the structure and behavior of the Peruvian judiciary were not enough to compensate for the general mistrust in judicial institutions among older generations, who had first-hand experience of the institution's dismal performance during the armed conflict.

To improve confidence in the argument about changes in the relative impact of the independent variables over time, I pooled the data from the three waves to test whether or not the coefficients differ across time. If Hypothesis 3 is correct, the effect of "procedural fairness" and "defendant culpability” should be moderated by a variable distinguishing between the on-set of the proceedings and the time when the ruling was imminent or had already materialized. In the case of “procedural fairness," the effect on trust in the judiciary should decline, whereas in the case of “defendant culpability," it should increase. Table 2 reports two models, each featuring an interaction between a dummy variable that 
distinguishes between the earlier (October 2007) and later (March and May 2009) stages of the trial proceedings, and the main independent variables. ${ }^{15}$ The results provide mix support for Hypothesis 3. Although both interaction terms have the expected sign, i.e. negative for procedural fairness (Model 4) and positive for defendant culpability (Model 5), only the former is statistically significant.

Table 2. Predicting Trust in the Judiciary II

\begin{tabular}{|l|l|l|l|l|}
\hline $\begin{array}{l}\text { Independent } \\
\text { Variables }\end{array}$ & \multicolumn{2}{|c|}{$\begin{array}{r}\text { Model 4: } \\
\text { Interaction: Time II } \\
* \text { Procedural Fairness }\end{array}$} & \multicolumn{2}{c|}{$\begin{array}{r}\text { Model 5: } \\
\text { Interaction: Time II } \\
\text { Defendant Culpability }\end{array}$} \\
\hline & Coefficient & S.E. & Coefficient & S.E. \\
\hline $\begin{array}{l}\text { Procedural } \\
\text { Fairness }\end{array}$ & $0.67 * * *$ & 0.24 & 0.11 & .15 \\
\hline $\begin{array}{l}\text { Defendant } \\
\text { Culpability }\end{array}$ & $0.33^{* *}$ & 0.16 & 0.12 & 0.33 \\
\hline $\begin{array}{l}\text { Time II } \\
\text { Procedural } \\
\text { Fairness } * \\
\text { Time II }\end{array}$ & $0.78^{* * *}$ & 0.24 & 0.03 & 0.32 \\
\hline $\begin{array}{l}\text { Defendant } \\
\text { Culpability } \\
* \text { Time II }\end{array}$ & $-0.88^{* * *}$ & 0.30 & & \\
\hline $\begin{array}{l}\text { Satisfaction } \\
\text { with } \\
\text { Democracy }\end{array}$ & $0.53^{* * *}$ & 0.11 & $0.53^{* * *}$ & 0.11 \\
\hline $\begin{array}{l}\text { Support for } \\
\text { Keiko }\end{array}$ & 0.03 & 0.14 & 0.02 & 0.14 \\
\hline
\end{tabular}

15 I rescaled "Procedural Fairness" as measured in March 2009 so that its values range from 0 to 1 like in the other two surveys. 


\begin{tabular}{|l|l|l|l|l|} 
Fujimori & & & & \\
$\begin{array}{l}\text { Trust in the } \\
\text { Armed } \\
\text { Forces }\end{array}$ & $0.48^{* * *}$ & 0.07 & $0.48^{* * *}$ & 0.07 \\
\hline Ideology & -0.04 & 0.13 & -0.02 & 0.13 \\
\hline Gender & 0.18 & 0.13 & 0.18 & 0.13 \\
\hline Age & $-001^{* *}$ & 0.004 & $-0.01^{* *}$ & 0.005 \\
\hline $\begin{array}{l}\text { Socio- } \\
\text { Economic } \\
\text { Status }\end{array}$ & -0.13 & 0.09 & -0.11 & 0.09 \\
\hline Education & -0.03 & 0.04 & -0.04 & 0.04 \\
\hline Indigenous & -0.06 & 0.13 & -0.07 & 0.14 \\
\hline & & & & \\
\hline Cut 1 & 0.99 & 0.69 & 0.56 & 0.71 \\
\hline Cut 2 & $2.88^{* * *}$ & 0.69 & $2.43^{* * *}$ & 0.71 \\
\hline Cut 3 & $4.97^{* * *}$ & 0.71 & $4.52^{* * *}$ & 0.73 \\
\hline $\mathrm{N}$ & 951 & & 951 & \\
\hline
\end{tabular}

Note: ${ }^{*} \mathrm{p} \leq 0.1 ; * * \mathrm{p} \leq 0.05 ; * * * \mathrm{p} \leq 0.01$ Coefficients are from ordered logistic regressions.

To better interpret the main result in Model 4, I estimated the marginal effects of a positive change in attitudes about procedural fairness for each category of the outcome variable at both points in time (Figure 7). The marginal effects at the earlier stages of the proceedings are statistically different from zero, whereas the opposite is the case for the later stages of the trial, indicating that evaluations of fairness matter before the ruling is imminent and before citizens are systematically exposed to images and commentary on the trial. As expected, at the early stages, a positive change in attitudes about procedural fairness decreases the 
likelihood of having no trust in the judiciary, and increases the chance that respondents will choose the other categories in the trust scale.

Figure 7. Marginal Effects of Beliefs in Procedural Fairness Across Time

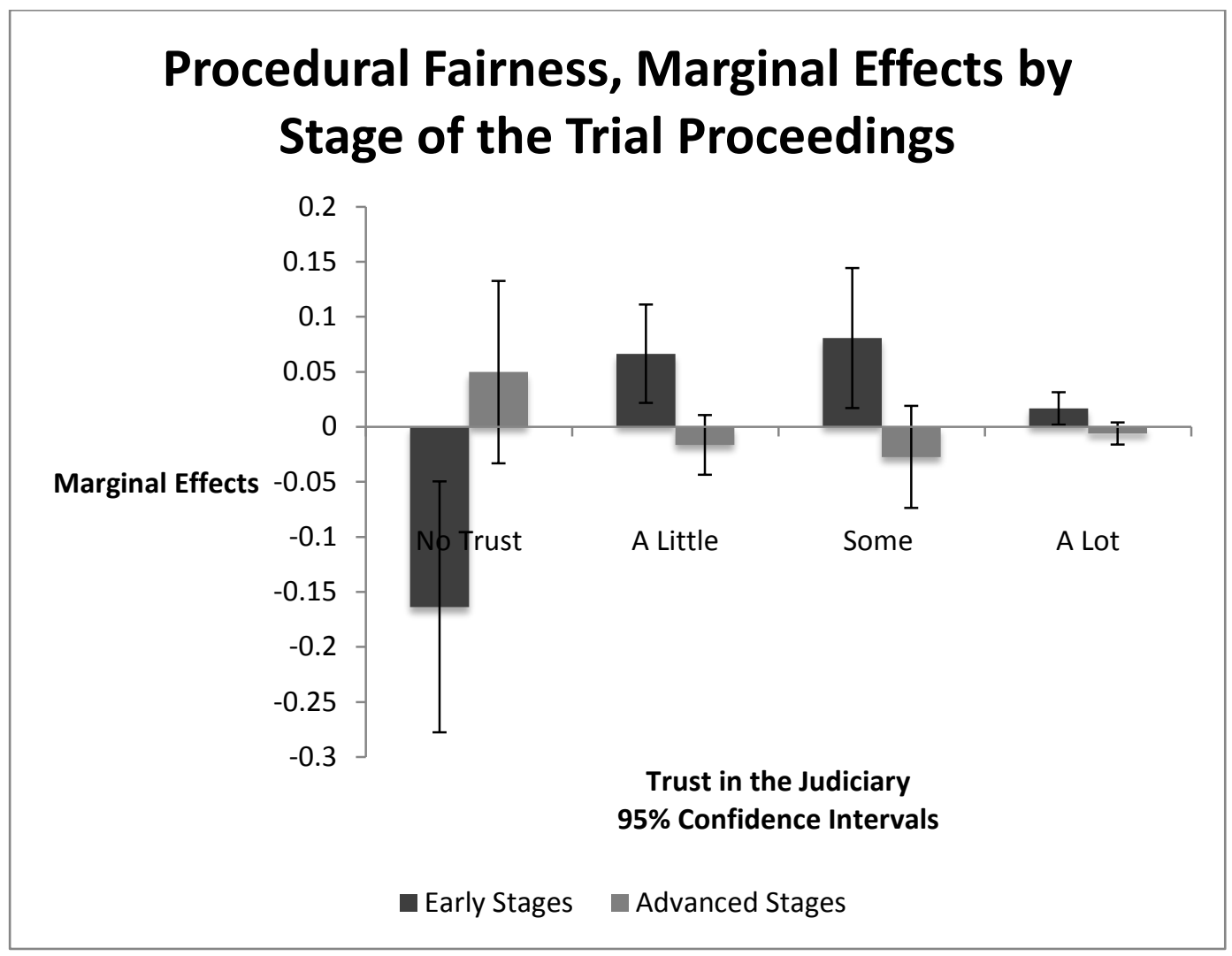

With regards to the increasing importance of "defendant culpability," the coefficient for the interaction term is not significant suggesting that there is no difference across time. However, consistent with the previous models, the marginal effects for the advanced stages (not shown) are statistically different from zero and in the expected direction for each of the categories of the outcome variable, whereas those corresponding to the early stages are not. Although these 
findings only halfheartedly support Hypothesis 3, they render it plausible and worthy of further investigation.

\section{Conclusion}

This paper explored the determinants of trust in the judiciary during the course of Fujimori's historic trial. The main goal of the analysis was to understand how different aspects of the way citizens evaluated this particular trial, shaped their attitudes towards courts in general. When the trial is in its initial stages, respondents' perceptions of procedural fairness have a strong and significant impact on trust in the judiciary. Once the ruling is imminent, or has already been handed down, what matters are views about defendant culpability. There is a shift in focus from process to outcomes. As individuals gather more information about the case, what becomes salient in the cognitive process of forming general attitudes towards the judicial branch are evaluations of how the court rules, not so much how the court handled the proceedings.

Several students of transitional justice argue convincingly that human rights trials strengthen the rule of law by, for example, reducing violence (Kim and Sikkink 2010). Others have speculated that these trials contribute to democratic consolidation by sending strong signals about the potential of courts to 
effectively weigh in during struggles over constitutional rights, and showing that the wrongdoings of the state can be effectively prosecuted (Smulovitz 1995; Acuña and Smulovitz 1997). In other words, human rights trials make citizens more trusting of the legal system. Despite shortcomings in the data, this article is to my knowledge the first attempt to systematically explore the causal mechanisms behind this argument, theoretically linking experience with trials and trust in the judiciary. I showed that at the individual level, higher levels of trust in the judiciary are associated with certain perceptions about the fairness of trial proceedings and defendant culpability.

The findings suggest lessons for the proponents of transitional justice. No matter how hard courts try to communicate norms about equality before the law and judicial impartiality, no matter how much they invest in turning these trials into teaching moments and publicity stunts by being extra vigilant of due process, their efforts have uncertain payoffs. The strongest result reported above is that courts' effectiveness in convincing people about their impartiality only matters as a legitimacy-building factor for a short period of time.

It is important to highlight that the analysis says nothing about long-term effects. It could be the case that evaluations of procedural fairness eventually become a heuristic used by citizens to judge judicial institutions. In addition, the nature of the data does not warrant any conclusions regarding the question of 
whether holding these trials in a particular time and place boosts average judicial legitimacy among the public in the medium to long run. What the data analyzed here tells us is how, within a short period of time, evaluations of human rights trials affect trust in the judiciary at the individual level. In order to assess the overall long-term impact of trials future research should collect panel or time series data on aggregate levels of trust in courts and evaluations of human rights trials.

The fact that perceptions of defendant culpability seem to become more relevant towards the end of the process gives us some clues about possible longterm effects. Although human rights trials may have the potential to consolidate diffuse support for courts among certain constituencies, they can also erode support among others due to the divisive nature of rulings. They are not a silver bullet bound to improve courts' reputation. Building a reservoir of goodwill among the public requires a series of salient decisions satisfying overlapping constituencies overtime. Having said this, whether or not beliefs in defendant culpability can influence trust in courts in the long run is likely conditioned by the extent to which trials continue to be a central issue in the public debate after rulings are handed down. In the Peruvian case, for example, the questions of Fujimori's guilt and the possibility of a pardon have resurfaced time and again, especially due to the excellent electoral performance of his daughter Keiko since 
2009. It is possible that these dynamics activated latent predispositions towards courts that were shaped during the course of the trial.

Finally, can the argument travel beyond Peru? Human rights trials are generally moments of intense drama, during which previously opaque courts are thrown into the political wilderness affording ordinary citizens a vivid encounter with the workings of the judiciary. But not all receive the same coverage and attention as the Fujimori trial. For my argument to work, citizens must be able to form consequential opinions about courts’ performance and sophisticated views about defendant culpability. If this does not happen it is unlikely that opinions expressed in a survey about human rights trials can override other determinants of trust in the judiciary when put to compete in a regression. Although the Fujimori affair was historic in nature, other episodes of transitional justice that received protracted media attention and involved divisive figures such as the Pinochet saga or the trial against Ríos Montt in Guatemala probably belong to the same causal universe. This contrasts with the Argentine case in which the recent wave of prosecutions involves numerous simultaneous trials. This diffuses the attention of the media, making the judiciary’s role in transitional justice an issue of low public salience (González Ocantos 2014). In any case, the fact that there is some support for the argument in a most likely case is promising and invites further empirical tests in other most and least likely cases. 


\section{References}

Aguilar, Paloma, Laia Balcells, Héctor Cebolla-Boado. 2011. "Determinants of Attitudes Towards Transitional Justice: An Empirical Analysis of the Spanish Case,” in Comparative Political Studies, 44(10): 1397-1430

Amnesty International. 2009. "International Report. Regional Overview: Americas.” http://www.amnesty.org/en/library/info/POL10/033/2009/en [last accessed June 11, 2012]

APRODEH. 2008. Podrán matar las flores, pero nunca las cantutas. Los familiares del caso La Cantuta: Actores en el proceso de búsqueda de verdad y justicia. Lima, Peru: APRODEH.

Baum, Lawrence. 2006. Judges and Their Audiences: A Perspective on Judicial Behavior. Princeton, NJ: Princeton University Press.

Brockner, Joel, Grant Ackerman, Jerald Greenberg, Michele Gelfand, Anne Marie Francesco, Zhen Xiong Chen, Kwok Leung, Gunter Bierbrauer, Carolina Gomez, Bradley Kirkman, and Debra Shapiro. 2001. "Culture and Procedural Justice: The Influence of Power Distance on Reactions to Voice," in Journal of Experimental Social Psychology, 37(4): 300-315

Burt, Jo-Marie. 2009. "Guilty as Charged: The Trial of Former Peruvian President Alberto Fujimori for Human Rights Violations.” International Journal of Transitional Justice 3 (3): 384-405.

Burt, Jo-Marie. 2007. Political Violence and the Authoritarian State in Peru: Silencing Civil Society. New York, NY: Palgrave Macmillan.

Caldeira, Gregory. 1986. "Neither the Purse Nor the Sword: Dynamics of Public Confidence in the Supreme Court," in The American Political Science Review, 80(4): 1209-1226

Casey, Gregory. 1974. “The Supreme Court and Myth: An Empirical Investigation,” in Law and Society Review, 8: 385-419

Collins, Cath. 2010. Post-transitional Justice: Human Rights Trials in Chile and El Salvador. University Park, PA: Pennsylvania State University Press.

Comisión de la Verdad y Reconciliación. 2003. Informe final. Lima, Peru: Comisión de la Verdad y Reconciliación. 
Cook, Timothy and Paul Gronke. 2005. “The Skeptical American: Revisiting the Meanings of Trust in Government and Confidence in Institutions," in The Journal of Politics, 67(3): 784-803

Dargent, Eduardo. 2009. "Determinants of Judicial Independence: Lessons from Three 'Cases' of Constitutional Courts in Peru (1982-2007).” Journal of Latin American Studies 41 (02): 251-278.

De la Jara, Ernesto. 2001. Memoria y batallas en nombre de los inocentes, Perú 1992-2001. Lima, Peru: IDL

Easton, David. 1975. "A Re-Assessment of the Concept of Political Support,” in British Journal of Political Science, 5(4): 435-457

Fagan, Jeffrey and Tom Tyler. 2005. "Legal Socialization of Children and Adolescents,” in Social Justice Research, 18(3): 217-242

Finkel, Jodi. 2008. Judicial Reform as Political Insurance. Notre Dame: University of Notre Dame Press.

Ford, Stuart. 2012. "A Social Psychology Model of the Percieved Legitimacy of International Criminal Courts,” in Vanderbilt Journal of Transnational Law, 45: $405-476$

Gibson, James. 2007. "The Legitimacy of the US Supreme Court in a Polarized Polity,” in Journal of Empirical Legal Studies, 4(3): 507-538

Gibson, James. 2004. "Does Truth Lead to Reconciliation? Testing the Causal Assumptions of the South African Truth and Reconciliation Process," in American Journal of Political Science, 48(2): 201-217

Gibson, James. 2002. "Truth, Justice and Reconciliation: Judging the Fairness of Amnesties in South Africa,” in American Journal of Political Science, 46(3): 540-556

Gibson, James, and Gregory Caldeira. 2009. Citizens, Courts, and Confirmations: Positivity Theory and the Judgments of the American People. Princeton, NJ: Princeton University Press.

Gibson, James, and Gregory Caldeira. 2003. "Defenders of Democracy? Legitimacy, Popular Acceptance and the South African Constitutional Court,” in The Journal of Politics, 65(1): 1-30 
Gibson, James, and Gregory Caldeira. 1992. "Blacks and The United States Supreme Court: Models of Diffuse Support," in The Journal of Politics, 54(4): $1120-1145$

Gibson, James, Gregory Caldeira, and Vanessa Baird. 1998. "On the Legitimacy of National High Courts," in The American Political Science Review, 92(2): 343-358

Gibson, James, Gregory Caldeira, and Lester Spence. 2003. “The Supreme Court and the U.S. Presidential Election of 2000: Wounds, Self-Inflicted or Otherwise?” in British Journal of Political Science, 33(4): 535-536

González-Ocantos, Ezequiel. 2014. "Persuade Them or Oust Them: Crafting Judicial Change and Transitional Justice in Argentina," in Comparative Politics, 46(4): 479-498

González-Ocantos, Ezequiel. 2012. The Collapse of Impunity Regimes: Legal Cultures, Strategic Litigation and Judicial Behavior. Ph.D. Dissertation. University of Notre Dame

Hammergren, Linn A. 1998. The Politics of Justice and Justice Reform in Latin America: The Peruvian Case in Comparative Perspective. Boulder, CO: Westview Press.

Helmke, Gretchen, and Jeffrey Staton. 2011. "The Puzzling Judicial Politics of Latin America: A Theory of Litigation, Judicial Decisions and Interbranch Conflict.” In Courts in Latin America, ed. Gretchen Helmke and Julio Ríos Figueroa. New York, NY: Cambridge University Press.

Hilbink, Lisa. 2007. Judges Beyond Politics in Democracy and Dictatorship: Lessons from Chile. New York, NY: Cambridge University Press.

Hirschl, Ran. 2008. “The Judicialization of Politics.” In Whittington, Keith, Daniel Kelemen and Gregory Caldeira eds. The Oxford Handbook of Law and Politics. Oxford: Oxford University Press.

Hoekstra, Valerie. 2000. "The Supreme Court and Local Public Opinion," in The American Political Science Review, 94(1): 89-100

Human Rights Watch. 2009. "Presunción Fundada.” http://www.hrw.org/en/reports/2005/12/20/presunci-n-fundada. [last accessed June 11, 2012] 
Huneeus, Alexandra. 2010. "Judging from a Guilty Conscience: The Chilean Judiciary’s Human Rights Turn.” Law \& Social Inquiry 35(1): 99-135.

Huntington, Samuel. 1991. The Third Wave. Norman: University of Oklahoma Press.

International Center for Transitional Justice. 2008. Living with Fear: A Population-Based Survey on Attitudes About Peace, Justice and Social Reconstruction in Eastern Democratic Republic of Congo. Berkeley: University of California, Human Rights Center

Justicia Viva. 2006. Cambios en el sistema de justicia. Lima, Perú: Justicia Viva.

Kim, Hunjoon and Kathryn Sikkink. 2010. "Explaining the Deterrence Effect of Human Rights Prosecutions for Transitional Countries," in International Studies Quarterly, 54: 939-963

Lisa Laplante and Kelly Phenicie. 2009. "Mediating Post-Conflict Dialogue: The Media's Role in Transitional Justice," in Marquette Law Review, 93: 251283

Lipset, Martin, and William Schneider. 1987. "The confidence gap during the Reagan years, 1981-1987,” in Political Science Quarterly, 102(1): 1-23

Listhaug, Ola. 1984. "Confidence in Institutions: Findings from the Norwegian Values Study,” in Acta Sociologica, 27(2): 111-122

López Medina, Diego. 2004. Teoría impura del derecho. Bogotá, Colombia: Legis.

Magaloni, Beatriz. 2003. "Authoritarianism, Democracy and the Supreme Court: Horizontal Exchange and the Rule of Law in Mexico." In Democratic Accountability in Latin America, ed. Scott Mainwaring and Christopher Welna. New York, NY: Oxford University Press.

Méndez, Juan. 1997. “In Defense of Transitional Justice.” In Transitional Justice and the Rule of Law in New Democracies, ed. A. J. McAdams. Notre Dame, IN: Notre Dame University Press.

Mondak, Jeffrey, and Ishiyama Smithey. 1997. "The Dynamics of Public Support for the Supreme Court,” in The Journal of Politics, 59(4): 1114-1142 
Nalepa, Monika. 2010. Skeletons in the Closet: Transitional Justice in PostCommunist Europe. New York, NY: Cambridge University Press.

Norris, Pipa. ed. 1999. Critical Citizens. Oxford: Oxford University Press.

O’Donnell, Guillermo, and Philippe Schmitter. 1986. Transitions from Authoritarian Rule. Baltimore: Johns Hopkins University Press.

Olson, Susan and David Huth. 1998. "Explaining Public Attitudes Towards Local Courts,” in Justice System Journal, 20(1): 41-61

Oyhanarte, Julio. 1972. “Historia del Poder Judicial,” in Todo es Historia, 61.

Pásara, Luis. 2010. Tres claves de la justicia en el Perú: Jueces, justicia y poder en el Perú; La enseñanza del derecho; Los abogados en la administración de justicia. Lima, Peru: Fondo Editorial de la Pontificia Universidad Católica del Perú.

Pereira, Anthony. 2005. Political (In)justice. Pittsburgh: University of Pittsburgh Press.

Pérez-Liñán, Aníbal, and Andrea Castagnola. 2009. "Presidential Control of High Courts in Latin America: A Long-Term View (1904-2006).” Journal of Politics in Latin America, 1(2): 87-114.

Prusak, C. T. 2010. "The Trial of Alberto Fujimori: Navigating the Show Trial Dilemma in Pursuit of Transitional Justice.” NYU Law Review 85: 867-2209.

Ron, James, and David Crow. Forthcoming. "Who Trusts Human Rights Organizations? Evidence from Three World Regions,” in Human Rights Quarterly

Rottman, David. 2007. "Adhere to Procedural Fairness in the Justice System," in Criminology and Public Policy, 6(4): 835-842

Rottman, David. 2005. Trust and Confidence in California Courts: A Survey of the Public and Attorneys, Part I: Findings and Recommendations. San Francisco, CA: Judicial Council of California/Administrative Offices of the Court.

Rottman, David, Randall Hansen, Nicole Mott and Lynn Grimes. 2003. Perceptions of the Courts in Your Community: The Influence of Experience, Race and Ethnicity. Williambsburg, VA: National Center for State Courts. 
Sarat, Austin. 1977. "Studying Legal Culture: An Assessment of Survey Evidence,” in Law and Society Review, 11(3): 427-488

Scheb, John, and William Lyons. 2000. "The Myth of Legality and Public Evaluation of the Supreme Court,” in Social Science Quarterly, 81(4): 928940

Sieder, Rachel, Line Schjolden, and Alan Angell, eds. 2005.The Judicialization of Politics in Latin America. New York, NY: Palgrave Macmillan.

Sikkink, Kathryn. 2011. The Justice Cascade: How Human Rights Prosecutions Are Changing World Politics. New York, NY: W. W. Norton \& Co.

Sikkink, Kathryn, and Carrie Booth Walling. 2007. "The Impact of Human Rights Trials in Latin America.” Journal of Peace Research 44 (4): 427-445.

Smulovitz, Catalina. 1995. “Constitución y Poder Judicial en la nueva democracia argentina. La experiencia de las instituciones.” In La nueva matriz política argentina, ed. Carlos Acuña. Buenos Aires, Argentina: Ediciones Nueva Visión.

Smulovitz, Catalina, and Carlos Acuña. 1997. "Guarding the Guardians in Argentina: Some Lessons About the Risks and Benefits of Empowering Courts.” In Transitional Justice and the Rule of Law in New Democracies, ed. A. James McAdams. Notre Dame, IN: Notre Dame University Press.

Staton, Jeffrey K. 2010. Judicial Power and Strategic Communication in Mexico. New York, NY: Cambridge University Press.

Stern, Steve J. 1998. Shining and Other Paths: War and Society in Peru, 19801995. Latin America Otherwise. Durham, NC: Duke University Press.

Sunshine, Jason and Tom Tyler. 2003. "The Role of Procedural Justice and Legitimacy in Shaping Public Support for Policing,” in Law and Society Review, 37(3): 513-548

Tanaka, Martín. 2006. "From Crisis to Collapse of the Party Systems and Dilemmas of Democratic Representation: Peru and Venezuela.” In The Crisis of Democratic Representation in the Andes, ed. Scott Mainwaring, Ana María Bejarano, and Eduardo Pizarro Leongómez. Stanford, CA: Stanford University Press. 
Tanaka, Martín. 2005. Democracia sin partidos, Perú, 2000-2005: Los problemas de representación y las propuestas de reforma política. Lima, Peru: Instituto de Estudios Peruanos.

Tate, Neal, and Torbjörn Vallinder, eds. 1995.The Global Expansion of Judicial Power. New York: New York University Press.

Teitel, Ruti G. 2000. Transitional Justice. Oxford, UK: Oxford University Press

Tyler, Tom. 1984. “The Role of Perceived Injustice in Defendants' Evaluations of Their Courtroom Experience,” in Law and Society Review, 18(1): 51-74

Tyler, Tom. 2001. "Public Trust and Confidence in Legal Authorities: What Do Majority Group Members Want for the Law and Legal Institutions,” in Behavioral Science and The Law, 19(2): 215-235

Tyler, Tom. 2004. "Procedural Justice.” In The Blackwell Companion to Law and Society, ed. Austin Sarat. London, UK: Blackwell Publishing.

Vanberg, Georg. 2001. "Legislative-Judicial Relations: A Game-Theoretic Approach to Constitutional Review.” American Journal of Political Science 45(2): 346-361.

Villarán, Susana. 2007. "Perú.” In Víctimas sin mordaza: El impacto del Sistema Interamericano en la jusiticia transicional en latinoamérica: Los casos de Argentina, Guatemala, El Salvador y Perú, ed. Fundación para el Debido Proceso Legal. Washington, D.C.

Vinjamuri, Leslie and Jack Snyder. 2004. "Advocacy and Scholarship in the Study of International War Crimes Tribunals and Transitional Justice,” in Annual Review of Political Science, 7: 345-362

Zalaquett, José. 1992. "Balancing Ethical Imperatives and Political Constraints: The Dilemma of New Democracies Confronting Past Human Rights Violations,” in Hastings Law Journal, 43(6): 1425-38. 